Article

\title{
New Representations of Religion and Belief in Schools
}

\author{
Martha Shaw \\ Education Division, School of Law \& Social Sciences, London South Bank University, 103 Borough Road, \\ London SE1 0AA, UK; shawm7@lsbu.ac.uk
}

Received: 14 October 2018; Accepted: 13 November 2018; Published: 16 November 2018

\begin{abstract}
Discussions around the future of Religious Education (RE) in England have focused on the need to address the diversity of religion and belief in contemporary society. Issues of the representation of religion and belief in Religious Education are central to the future of the subject. This article draws on research into key stakeholders' views and aspirations for RE to map an alternative representation of religion and belief to that found in existing approaches that universalise, sanitise and privatise religion. The data reveal a thirst for the study of a broader range and a more nuanced understanding of religion and belief. This incorporates a focus on religion and belief as identity as well as tradition, the study of the role of religion in global affairs as well as the controversies and challenges it can pose for individuals and the exploration of religion and belief as fluid and contested categories. What may be described as a contemporaneous and sociological turn, moves beyond the existing binaries of religious/secular, public/private, good/bad, fluid/static that shape much existing representation, towards a representation of the 'real religion and belief landscape' in all its complexity.
\end{abstract}

Keywords: Religious Education (RE), representation; misrepresentation; sociological turn; categories

\section{Introduction}

Changes in the religion and belief landscape of the UK over recent decades have been significant and are well documented in contemporary sociological research (see for example, Catto and Woodhead 2012, 2012; Davie 2015). Yet, as Dinham and Francis observe, there is a growing gap between this real religious landscape and that imagined by the majority (Dinham and Francis 2016). This gap is related to the diversity of beliefs, diversity within traditions and the nature of 'being religious'. The complexity of this landscape and its implications for society and its individuals is not easily grasped and poses a challenge to educators seeking to promote an understanding that prepares young people for engagement with religion and belief diversity in their everyday encounters, in communities and work places.

Religious Education (RE) in England has been widely criticised for failing to get to grips with the diversity and complexity of religion and belief (see for example, Jackson 1997; Barnes 2012; Ofsted 2013; REC Religious Education Council of England and Wales). Much critique has focused on the issue of representing the diversity of and within traditions and the 'nature' of religion (see Jackson 1997, 2004a, 2004b; Wright 1993, 2008; Barnes 2014). Attention has been focused on the shortcomings of various pedagogical approaches, in particular the phenomenological approach, that universalises, sanitises and privatises religion within a secular liberal mould. This is mirrored in policy too, where a narrow, static representation is apparent (Revell 2012; Jackson et al. 2010). These debates raise key questions about how we frame religion and belief in policy and practice.

This article draws on findings about the views of key stakeholders in learning about religion and belief in the RE for Real study (Dinham and Shaw 2015). Participants' views on the content of school 
$\mathrm{RE}$ are analysed in relation to existing debates around the representation of religion and belief to ask what kind of representation meets the aspirations of key stakeholders.

These findings reveal an appetite for a much broader and nuanced understanding of religion and belief. A piecemeal understanding of some aspects of some religions provides only a partial window on the complex realities. How can education prepare pupils more adequately to engage with this complexity? This article suggests the need for a contemporary and sociological turn in the representation of religion and belief in curricula in order for pupils to gain a more nuanced understanding of their complex role and nature in society and in the lives of its members. The importance of representation lies therefore in both the intrinsic value of such understanding and its instrumental purpose of preparing young people for engagement in the global society of which they are part.

\section{Methodology}

The initial research that underpins this paper is a national project, $R E$ for Real, undertaken in England between July 2014 and November 2015. This was a qualitative study seeking key stakeholders' views on learning about religion and belief in schools. This research comprised semi-structured interviews with teachers (97), parents (34) and focus groups ( 9 with 10 pupils each) with Year 10 pupils (aged 14-15) across 19 secondary schools. The schools were chosen to represent a geographical spread and a mixture of urban and rural settings. Five are community schools ${ }^{1}$ and fourteen academies ${ }^{2}$. Of these, six are Church of England academies, seven have 'no religious character' and one is ecumenical. Voluntary aided and free schools with a religious character were not included. Due to the complexity and specificity of their context within the English schools system, they are more likely to teach RE in accordance with a faith tradition. It was therefore decided that they would best be handled via a separate study. The sample of 97 teachers was made up of 29 RE specialists, 49 non-specialists in RE and 19 members of senior leadership teams. This sample sought to reflect the situation across most secondary schools, in which more than 50\% of RE teachers have no qualification in the subject (APPG All Party Parliamentary Group on Religious Education). It also sought to explore views from across the humanities and related subject areas such as Citizenship.

Ten employers were also interviewed. These were self-selecting from a purposive sample drawn to represent a mixture of organisations within the public and private sectors. In each organization, the participant held a position at Chief Executive/Director level, or had responsibility for employing staff. Participants' identities have been entirely anonymised, including in reference to their school location or workplace.

Interviews were transcribed and coded using NVIVO. Thematic analysis (see Boyatsis 1998) was undertaken in relation to three areas listed below. A full discussion of the methodology and findings of the project are reported in Dinham and Shaw $(2015,2017)$.

The research centered on three questions:

1. How do stakeholders understand the purpose of RE? ${ }^{3}$

2. What are stakeholders' aspirations regarding the content of RE?

3. What do stakeholders think the teaching and learning about religion and belief should look like, both inside RE and outside, in the wider school environment?

The results presented in this article relate to the second theme: aspirations regarding content and as such, are part of a much larger data set, which looks at learning about religion and belief inside and

State schools controlled by the local council.

Academies are publicly funded, independent schools, run by Academy Trusts. They receive their funding directly from the government, rather than the local council and do not have to follow the National Curriculum.

3 The RE for Real research asked participants about "learning about religion and belief" rather than specifically about Religious Education (RE). However, due to the structure of the English curriculum in which RE is a discrete subject area, responses (unless otherwise specified) are taken as relating to RE. 
outside the classroom in other spaces such as the act of collective worship and school ethos. Issues of representation have implications in these spaces too and connections between these and the RE space are discussed elsewhere (Dinham and Shaw 2015, 2017). The focus of this article is on issues of representation within the RE classroom. This article asks what kind of representation of religion and belief meets the aspirations of key stakeholders for the content of RE? Participants' views on content are analysed in relation to debates on the representation of religion and belief in curricula to suggest a new set of representations that better prepare pupils to engage with the real religion and belief landscape.

\section{Aspirations on Content}

\subsection{More Breadth}

Since the late 1970s, a 'world religions' approach has dominated RE in England. The 1988 Education Reform Act, reflecting the multiculturalist policy of the time, requires RE in England to reflect the "fact that the religious traditions are in the main Christian whilst taking account of the teaching and practices of the other principal religions represented in Great Britain" (UK Parliament 1988, Sct. 8.3). Despite the 'other principle religions' not being specified, this has led to syllabi focused on the 'big six' —Christianity, Judaisim, Islam, Hinduism, Sikhism and Buddhism, with other religions generally omitted. This lack of breadth is further consolidated at GCSE ${ }^{4}$, where pupils studied one and more recently two major traditions. Despite the increased religion and belief pluralism in the UK, much RE and many RE text books still refer to the 'big six', an idea that is largely unquestioned (Revell 2012). That RE needs to get to grips with the diversity of religion and belief has been a longstanding criticism of the UK's Office for Standards in Education (Ofsted 2010, 2013) and one recognised by many in the RE community (see REC Religious Education Council of England and Wales; Barnes 2012; Jackson 2004b; Revell 2012; Thobani 2017).

The RE for Real research found that whilst the 'big six' mantra remains evident, particularly amongst some teachers and parents, many others, particularly pupils, wanted to learn about a broader range of beliefs. An overarching theme in participants' views on the content of RE was that it should better reflect the religion and belief diversity that exists in British society today. Many in this sample felt that an understanding of diversity must go beyond a superficial knowledge of the major faiths, either those represented in Britain or the 'world religions' and must include non-religious worldviews. Amongst all participants, this was most often expressed in terms of pupils being prepared for the diversity they will encounter:

"We live in a country with loads of different religions and I think we should learn about each different one, so if you do come across them, you know what they're on about, and you know who they are." (Pupil)

“They don't learn about minority religions and I think they should." (Teacher)

This appetite for breadth was voiced most strongly by pupils. Although it was an aspiration for teachers too, who held an ideal of "breadth meeting depth":

"I think in order to get enough depth in the subject you need to study a few main ones ... then bringing in some non-popular denominations, not just Christian ones ... for example the Amish people ... or Branch Davidians." (Teacher)

Many however, felt that such an ideal was compromised by structural pressures:

4 The General Certificate of Secondary Education (GCSE) is an academic qualification, taken in various subjects at age 14-16 in England, Wales and Northern Ireland. 
"I'd say as wide a range as possible within the constraints of the curriculum." (Teacher)

This reflects the lack of curriculum time allocated to $\mathrm{RE}^{5}$ and, particularly the constraints of the GCSE specifications.

\subsection{Including the Informal}

The focus on world religions is underpinned by the phenomenological approach to RE developed by Ninian Smart in the 1960s. This approach has been widely criticised for its reductionist and universalist portrayal of religions. For Wright (1993), it makes all religions culturally relative traditions embracing a universal theology and common universal religious experience. Wright argues that the liberal/phenomenological approach to RE perpetuates a myth that the variety of world faiths have a common nature and structure that can be studied in a thematic way, which does not do justice to the complexity and true nature of the faiths concerned (Wright 1993). The idea that all belief systems are characterised by a set of shared dimensions has resulted in the development of schemes of work shaped by themes such as 'founding fathers' and 'holy books'. The effect is that religions and belief systems that do not fit neatly into such a framework are side-lined. This perpetuates the myth that other traditions (Confuscianism, animism, shamanism etc.) are not 'real religions' because they do not fit the paradigm (Revell 2012): "When asked to explain why a practice like animism, which is found in every continent, is never normally covered in RE lessons, students often explain that its lack of structure or core rituals, the absence of sacred texts, priesthood or places of worship mean that it is too amorphous to be included in a curriculum and too disparate a practice to be considered a discrete body of knowledge" (Revell 2012, p. 7).

This leaves little room for exploring more informal, non-institutionalised beliefs and practices which, as documented in contemporary research, are a growing part of the religion and belief landscape in the UK. A wealth of sociological research points to the demise of 'old style' religion characterised by national, hierarchical structures, passive membership and formal practices and the increasing dominance of 'new style' religion, with less structured forms of practice, participation and authority (Woodhead 2012a). Many participants in the RE for Real sample expressed an interest in the informal:

“Obviously you can't look at them all, but I think it's important to look at how people have beliefs but they may not be within a formal religion." (Parent)

"It's like a mind map of religion because within that you've got religions that aren't necessarily religious but are spiritual." (Teacher)

These responses suggest the need to challenge the orthodoxies apparent in much existing representation of religion and belief in curricula. They suggest the need for the consideration within RE of the rise of spirituality (see Woodhead 2012a, 2012b, 2014) and sociological concepts such as Davie's believing without belonging that capture the complexity of personal faith and the relationship between the formal and the informal (Davie 1994).

\subsection{Non-Religious Worldviews}

The phenomenological approach emerged from a context of 'secular education' (Thobani 2017) within which the secular was considered the neutral, logical position from which religions could most effectively be studied. In a rejection of the confessional approach that had dominated RE up until the 1960s, the world religions approach encouraged an impartial, secular, objective study of religions. Although, as noted by Thobani (2017), Smart's later work does suggest the study of secular alternatives

5 The 2013 NATRE survey reports reduced curriculum time devoted to RE since the introduction of the English Baccalaureate (EBacc) - the performance measure for schools through which Government determines the subjects most important to study as GCSE, from which RE was excluded (National Association of Teachers of Religious Education NATRE). 
such as Humanism, Marxism and Maoism, the application of the phenomenological approach in schools, in line with the existing legislation, often ignores non-religious worldviews. Thus, secularity, set in opposition to religion, has been the lens, not the object of study. Yet, as might be expected in a context in which over half the British public do not identify with a religion ${ }^{6}$, this sample indicates overwhelming support for the inclusion of non-religious worldviews:

"I think they (non-religious worldviews) are just as important to learn as like Christianity because it's still a form of belief." (Pupil)

"They need to know about all the major ones plus Humanist, secular religions, ones that don't actually believe that there is a god but still want to have an ethical base." (Parent)

"That's (non-religious worldviews) important too, because not everyone you meet is religious." (Pupil)

The near universal consensus amongst this sample that pupils should learn about non-religious worldviews suggests that the representation of religion and belief in curricula should better reflect the society in which it operates and the diversity of encounters that pupils experience.

\subsection{Exploring Categories-The 'Religious' and the 'Secular'}

When non-religious worldviews are included in curricula, these are most often limited to recognised belief systems such as Humanism or Atheism, which fit more easily into a systematic, dimensional, phenomenological approach (Thobani 2017). These are often presented as in opposition to the religious. This is apparent in the responses from parents who tended to be supportive of the inclusion of non-religious worldviews in curricula to "balance" the religious:

"Yes definitely [include non-religious worldviews]. That's the flipside." (Parent)

As recognised by Barnes "the concept of religious diversity, if it is to be both meaningful as a descriptive term and relevant to curriculum planning and pedagogy, needs to include some reference to the different varieties and degrees of religious skepticism that exists within the United Kingdom" (Barnes 2012, p. 68). Rather than presenting beliefs or worldviews as either religious or secular, the reality is often less clearly defined. Some teachers' responses questioned an uncritical employment of the categories 'religious', 'secular', 'spiritual' etc.:

"I'd want them [pupils] to think more broadly about what we class as religion too. There are people that dance round Stonehenge naked because the sun's up. Does that fall under the remit? Definitely it does of spirituality." (Teacher)

There is recognition here of the nuanced intersection between religious and non-religious beliefs, that the reality is more complex than often assumed. Understanding the nuances of non-belief is an area gaining increasing importance in the sociology of religion and non-religion. Whilst there is an increase in those who claim no religion, this does not indicate a simple rise in atheism. For example, amongst the 'fuzzy nones' identified in Woodhead's research, $43 \%$ are atheist, $40 \%$ are agnostic, and $16 \%$ believe in God (Woodhead 2014). Research into the growth and experiences of Britain's 'nones' (see for example Lee 2015) presents alternative ways of understanding the secular-looking at different aspects of so-called secularity as 'insubstantial' —involving merely the absence of religion-and 'substantial' - involving beliefs, ritual practice, and identities that are alternative to religious ones. This includes the growth of the more prominent movements like New Atheism and Sunday Assembly

6 According to the British Social Attitudes Survey, 2017, more than half (53\%) of the British public now describe themselves as having "no religion", up from $48 \%$ in 2015. (http:/ / www.natcen.ac.uk/news-media/press-releases / 2017 /september/ british-social-attitudes-record-number-of-brits-with-no-religion/). 
as well as more individualised ways of being secular. This body of research suggests that making sense of secularity, irreligion, and the relationship between them is crucial to our understanding of contemporary society. A critical engagement with the categories 'religious' and 'secular' would both present pupils with more breadth in terms of representing the religion and belief landscape and more depth in terms of understanding how religion and belief operate and are experienced.

\subsection{Lived Religion}

The dominance of a world religions approach encouraged the systematic study of the major traditions through their 'shared characteristics' and as discrete belief systems in which, in line with the ideals of multiculturalism, each religion is given equal treatment (aside from the dominance of Christianity) and studied in the same, objectified way. This approach was bolstered by the creation of Standing Advisory Councils for RE (SACREs) through which representatives of the major faiths sought to ensure that their tradition was given equal footing and valid representation. A result of the systematic, abstracted and objective study of religions within this framework is that religion (and non-religious worldviews where included) are represented as static blocks of belief and practice.

This approach is reinforced by an 'accountability agenda' in English schools in which high stakes testing is used to hold schools publicly accountable for pupil achievement. Fancourt (2015) argues that the separation in policy of Grimmitt's widely adopted, interdependent aims for RE-'learning about religion' and 'learning from religion' (Grimmitt 2000) —and their framing as 'attainment targets' within a neo-liberal culture of scrutiny and accountability leads to narrow and competing conceptions of religion in RE as either blocks of belief and practice that can be objectively studied or as sources of pupils' personal development. Fancourt outlines how RE's omission from the national curriculum and consequent accidental marginalisation led to the development of new non-statutory syllabuses (SCAA School Curriculum and Assessment Authority, School Curriculum and Assessment Authority), which, in seeking to align RE with national curriculum subjects, adopted knowledge and skills-based, measurable, assessment-linked learning objectives (Fancourt 2015). Within this system, knowledge of beliefs and practices as isolated, monolithic, 'objective facts' becomes the measure of pupils' learning-a process that obscures the complexity of the subject under study.

Whilst the study of beliefs and practices was seen as important by pupils in this sample, they are more interested in how individuals and communities make sense of and experience religion in their daily lives;

"You're not going to meet a Christian and start talking about how Jesus was born, or Adam and Eve, which is something we cover a lot in RE ... you should learn more about what people do in everyday lives." (Pupil)

"I think that while we should be taught about ceremonies and things like that in religion, I don't think it should be the main topic because I find I know more about ceremonies than I do about everyday life. I'd rather know how they lead [their life] rather than just what happens once a year ... because that's not everything about the religion. What they do in their day to day lives, that's the religion." (Pupil)

This sample recognises that experience of being religious is complex. Rather than the study of belief and practices as monolithic blocks, participants are interested in 'lived religion'; how religion and belief is experienced by individuals and communities. The responses present a challenge to the homogenisation of religious traditions, demonstrating an awareness of the importance of internal diversity. Pupils particularly challenged the way in which religions are presented and stressed the significance of individual interpretation resulting in a diversity of rule following:

"It's such a broad thing, so to say, like, Christians believe that like, having women Bishops is wrong ... is a really difficult thing to say ... there could be some people who are Christian who completely don't think that". (Pupil) 
"They should teach you different points of view within a religion". (Pupil)

“It's not something you can just learn as a block. It's individual what you believe." (Pupil)

Many such comments were made in relation to Islam, revealing a particular, recognised tendency in curricula to overlook diversity among Muslims (Thobani 2017; Revell 2012):

"You need to cover the fact that not everyone that comes from that religion actually acts and thinks in that (extremist) way ... You need to know how different people interpret their religion." (Pupil)

As well as individual interpretation of traditions, responses indicate an interest in the nature of religious adherence. There is recognition within this sample that 'being religious' can mean different things for different people:

"It's important for pupils to know that there are lots of people that would tick a religious box but not practise it, and that that doesn't make their religion any less valid than those following it more closely ... There are spectrums everywhere." (Teacher)

This acknowledges the increase in 'nominal religion', a growing trend, particularly within Christianity for people to self-categorise as religious, without strict, or indeed any adherence to ritual or practice (see Day 2011). Participants are wary of putting people in boxes, recognising too that religious adherence can change throughout the life cycle, rather than presenting it in terms of set, static categories:

"You have people who convert because it's fluid. There are people who stick, people who quit and people who wander in between ..." (Teacher)

Participants' focus on 'lived religion' suggests the need, as recognised by Barnes, for curricula to embrace all forms of diversity, from "highly eclectic versions of spirituality, to personal appropriations of particular religions and to traditional forms of the different religions." (Barnes 2014, p. 239).

\subsection{Change and Fluidity}

This tendency in curricula to focus on religions and non-religious traditions as discrete belief systems, suggests that they are static, unchanging entities that can be objectively observed from the outside. Such a focus denies the dynamic and fluid nature of traditions and the consequent changes to the religion and belief landscape, both in relation to demographics and the evolution of traditions through encounter. As identified by Jackson, the view of cultures taken in the 2004 non-statutory National Framework for Religious Education, in "using the language of separate bounded cultures and downplaying the contested and challenging cultural forms and syntheses that are the reality across the generations" (Jackson 2004b, p. 220) provides pupils with a narrowed understanding of the complex landscape.

Participants in the RE for Real study thought that curricula should better reflect this dynamism:

"Religion has adapted ... with (the) times ... when Sunday trading laws came in half my grandma's family were outraged because they'd rather have a cup of tea without milk than go to the shop and get it. Times have changed, Things have changed. People believe in Karma nowadays." (Teacher)

"I think it lives and breathes. It's the same with language, it's eternally changing. We should teach it as that." (Teacher)

This suggests the need for a more dynamic understanding of culture and of religion such as that embraced in Jackson's Interpretive approach to RE (Jackson 1997) and models of intercultural education (Council of Europe 2008; UNESCO 2006; Jackson 2016). The above models are influenced 
by an understanding of culture as 'demotic discourse' (Bauman 1999), recognising internal diversity, inter-generational difference and fusion and bringing representation closer to the empirical data and to the experience of learners (Jackson 2004b, 2016). This does not imply ruling out the study of 'prototypical properties' of religious or non-religious traditions (Wright 2008) but does question the relevance of a focus on religions as discrete belief systems and the presentation of beliefs and practices as static.

Analyses of transnational religion present illuminating examples of everyday, lived, blended religion (see Levitt 2006), characterised by hybridity and fluidity as individuals improvise new religious blends from cultural materials available to them (McCloud 2017, p. 17). Likewise, Pasura and Erdal (2016) provide examples within the Catholic faith of the creation of hybrid religiosity intersecting with a variety of identities and understandings of nationhood. Such examples highlight the importance of paying attention to everyday lived religious experience and the complexity of religion as identity, of the relationship between religious and national identity and importantly, demonstrate the two-way process of change- that "practices are being transformed in both sending and receiving contexts" (Pasura and Erdal 2016, p. 7). In our globalised classrooms, this sends an important message too about integration - that it is a two-way process; "The circulation of religious practices and beliefs across borders, as migrants travel back and forth from their adopted country and homeland, shape the transnational religious field in both sending and receiving countries" (Pasura and Erdal 2016, p. 6).

These examples of bricolage (Hervieu-Léger 2000) reflect both the changing nature of religious belief and practice, and highlight the need to move beyond a boundaried representation of traditions:

"Beliefs and practices are important, but it needs to be coupled with the sociological; the changing nature of religion. Religion is clearly changing very rapidly. From a sociological point of view, is there even such a thing as Christianity anymore?" (Teacher)

\subsection{Tradition Versus Identity}

The focus on fluidity enjoins a shift in understanding religion and belief as primarily tradition to understanding them as identity. Hybridity and 'religious bricolage' (Hervieu-Léger 2000) play out at the level of individual identity too. As Jackson notes: "Personal world views might mirror particular religions or secular humanism, but are often more eclectic, for example, combining elements of more than one religion (e.g., Buddhism and Judaism), or features of one or more religions and Humanism (e.g. bringing together an atheistic stance with elements of Christian ethics and spirituality)" (Jackson 2014, pp. 67-75).

Young people, particularly immigrants, are increasingly defining their identity in terms of their faith. The 2001 disturbances in the Northern English towns were perhaps a marker in the discourse around identity from one based on ethnic to religious grounds as, after 9/11 'race riots' became redefined as 'faith riots'. Indeed, peoples' experience of 'faithism' matches and compounds racism. Yet the intersection between religion or belief, ethnicity, nationality and other identity markers is complex-“religious identities are never only 'religious'" (Sheedy 2017, p. 39) and they are fluid. As Moulin and Schirr demonstrate in their study of young Muslims in London, self-identification is a complex nexus of multiple, shifting markers, demonstrating the "complexity of Muslimness as a contested and minoritised category with ethnic, racial, national, and political features, as well as religious ones" (Moulin-Stozek and Schirr 2017, p. 582). Their study illustrates the fluid nature of self-identification, and "disidentification" in relation to essentialised representations of religion (in this case, negative assumptions about Islam), as the authors demonstrate that "no one minority identity, such as 'religious', is solely appropriate to account for the subtle agency of Muslim adolescents' self-understanding and self-representation" (Moulin-Stozek and Schirr 2017, p. 581).

As Revell (2012) has argued, lived religion for many Muslims is a process of marginalisation and hostility and to understand Islam necessitates a critical understanding of the political and policy contexts in which it is perceived and lived. Participants in the RE for Real study are interested in how religious identification is understood and shaped by societal assumptions and prejudices: 
"Why is it embarrassing to say you're a Christian, and what does that say in a "Christian country", that it's not embarrassing to say you're a Muslim?" (Teacher)

"The whole Islamophobia thing needs to be explored." (Teacher)

These quotes suggest an appetite for an exploration of identity as 'technologies of the self' (Foucault 1988), that considers the social context and the power of dominant discourses. Moulin-Stozek and Schirr (2017) employ the concept of 'disidentification' to emphasise this flexibility of self-identification, recognising too that often it is not a question of drawing on one or more distinct identities, be they 'religious' or otherwise. Rather, disidentifications can place actors in-between solid identity poles, in sites of "creative production" (Moulin-Stozek and Schirr 2017, p. 583). An understanding of the fluid and contested nature of identity that is the experience of young people is a huge shift away from the universalizing and simplistic representations often found in materials used to teach about world religions (Jackson et al. 2010). A shift in understanding that incorporates this complexity can help pupils to understand the real nature of religion and belief. Such intercultural models can also support RE to fulfil its much-cited role in helping to overcome stereotypes.

\subsection{Engaging with Controversy}

$\mathrm{RE}$ is often seen as a powerful vehicle for community cohesion, with potential to break down stereotypes and promote mutual respect and tolerance in a diverse society (DSCF Department for Children, Schools and Families; REC Religious Education Council of England and Wales; Ofsted 2010, 2013; APPG All Party Parliamentary Group on Religious Education). In suggesting that all religions are equally worthy of respect and tolerance, curricula often emphasize the common ground between religious faiths, drawing out points of similarity, or reducing them to a universalised essence. The effect is to side-step difference and risk avoiding the controversial aspects of religion, paradoxically perpetuating essentialised and stereotypical representations of religion (Moulin 2011; Revell 2012; Thobani 2017). Many are critical of this instrumentalisation of RE as a vehicle for the promotion of Western liberal values (Chater and Erricker 2013; Barnes 2006, 2014; Thompson 2010) resulting in the misrepresentation of religion as liberal and benign, which is "at best partial and at worst misleading" (Chater and Erricker 2013). This "safety first" representation obscures the reality of religion in society and denies its controversial nature (Wright 1993, p. 65). In seeking to overcome the stereotype that religions are violent, such representations risk falling into another cliché that claims all religions are inherently good or peaceful (Sheedy 2017).

The focus on commonality is perpetuated by recent policies, such as Prevent and the duty to promote Fundamental British Values through which a security agenda impacts particularly upon representations of Islam. There seems to be a tendency to compensate for negative images perpetuated in the media, and in a desire to breakdown stereotypes, to stress the positive side of Islam, to avoid controversy or anything that could be deemed illiberal. Pupils, however, are aware that this is not the full picture and are keen to study 'real' religion, 'warts and all':

"I don't think you can just learn the good stuff in RE, you've got to look at the downsides, I've never learned about that." (Pupil)

"I think it's interesting when we look at big disasters and the terrorists." (Pupil)

"They need to know about Jihadi John and that kind of thing." (Parent)

A far cry from relativist, phenomenological approaches that decontextualise and sanitise religion, this calls for the study of the role of religion in global affairs as well as the controversies and challenges it can pose for individuals. Participants are interested in 'religion in society', ascribing more relevance to the controversial role of religion in current affairs than is given emphasis in current curricula:

“Although it won't come up in their GCSEs, it's (Charlie Hebdo attack) really relevant. That will have far more impact on their lives than what Christians think of divorce." (Teacher) 


\section{9. 'Contemporary Religion in Society'}

The focus on the positive side of religion relates to the idea of religion as private, an individual concern based on personal beliefs (Sheedy 2017). This misconception is often seen when acts of violence or terrorism are described as having nothing to do with the 'real' religion. Walsh contends that the concept of religion as belief is a Western construct (Walsh 2017), with its roots in the ideology of political liberalism in early modern Europe (Stoddard and Martin 2017). The roots of a public/private binary and its entrenchment in representations of religion and belief in RE are summarized by Thobani thus:

"Secularism in post-Enlightenment Europe, as a political doctrine, has entailed the privatisation of religion through its exclusion from the public domain. This socio-historical transformation is foregrounded by the critics of the phenomenology of religion as explaining in part its conception of religion as having more to do with the transcendent, other worldly realm than with the affairs of this world. It has led to the study of religious and secular belief systems in a reified form, detached from their political and social matrix in which there exist intricate webs of connections between orientational beliefs and social institutions". (Thobani 2017, p. 617)

This divorcing of religion from social and political contexts is apparent in public discourse and demonstrated in a recent ComRes survey in which $64 \%$ of respondents agreed that "most religious violence is really about things like politics, socio-economic issues, or Western foreign policy." (ComRes 2018) The representation of religion as private does little to promote understanding of religion, not least in shielding it from "rational scrutiny and criticism" (Barnes 2012, p. 71). Neither does it align with the 'lived religion' that interests participants:

"I think it's important to link religions to what's actually going on in society." (Pupil)

"We need to learn about how it [religion] mixes into politics." (Pupil)

"We need to look at religions and their core beliefs and practices, but then examine believer's

lives, their role in society, and religion's role in shaping society." (Teacher)

These responses illustrate an appetite for thinking about religion, not just in terms of belief, but as 'a collection of 'variously linked social practices'" (Walsh 2017, p. 81). Participants are interested in the social nature of religion as well as the private/individual negotiation of religious and non-religious identities and how these two intersect.

\section{Conclusions}

The data presented in this article reveal an appetite for learning about a broader range and a more nuanced understanding of religion and belief. Yet the kind of religion and belief found in much existing curricula in the UK falls short of representing the complex reality with which pupils engage. These data suggest the need for a new set of representations that challenge old orthodoxies. Dominant representations can be seen as rooted in a set of false binaries that restrict understanding: religious/secular, public/private, good/bad and fluid/static. These binaries are reflected in research on how religion and belief can be re-represented in policy more broadly (Baker et al. 2018) and are particularly pertinent to RE. The challenge apparent at policy level is reflected in practice in the RE space.

A key part of this challenge is a re-examination of the category of religion and its relation to the secular. The universalising, privatising and sanitising of religion in curricula, shaped by pedagogical and policy concerns, is based on a foundational understanding of religion as in opposition to the secular. Yet the relationship between religion and secularity is complex and nuanced. Drawing on the sociology of religion to critically examine the nature of religion in society exposes the need to re-examine these categories, to examine the "manifestations of the secular in a complex of relations with the religious-from the collaborative to the oppositional" (Thobani 2017, p. 616). 
This religious/secular divide is fundamental in laying the ground for a series of misconceptions and false binaries that shape the misrepresentation of religion and belief. Consideration of these binaries and the conception of religion of which they form part are key to understanding the 'real religious landscape'. A good/bad binary is expressed in the promotion of tolerance through the representation of all religions as good and peaceful at the core and the bracketing out of controversial aspects as 'not real religion'. In seeking to highlight shared values or 'common ground' between different religions, difference and controversy are side-lined, resulting in a partial understanding and one that is at odds with the experience of pupils.

This is interwoven with a public/private binary that sees true religion as being about beliefs, a private affair, free from the messy, secular world of politics. Yet as a glance at any newspaper tells us, religion and politics are intrinsically bound. Likewise, identities, including the religious, are inherently social. A focus on religion as identity invites consideration of the negotiation between the public and the private that is part of 'lived religion'.

Another misconception lies in a solid/fluid binary. Religions and non-religious worldviews are often presented as static blocks of belief and practice that can be objectively studied. Yet, as examples of identity politics and transnational religion demonstrate, encounter in our globalised world generates a fusion of experiences that change the nature of self-identification, belief and practice, emphasising the fluidity of religion and non-religion. There are indeed doctrines that can be labelled 'typical' of traditions, just as there are practices that are traditional within certain communities, yet these are constantly negotiated and new constructions of belief, practice and identification developed.

Challenging these binaries broadens the remit of what is classed as 'religious' or 'secular', opening the space for a representation of religion and belief that is reflective of the real landscape and the lived reality. This includes the consideration of the changing nature of religion and belief, a focus on religion as negotiated identity as well as tradition and the role of religion and belief in current affairs and controversies.

The need for a more nuanced understanding of 'religion' and 'non-religion' has gained recognition in the Commission on Religious Education's national plan for RE (CoRE Commission on Religious Education). Here, specific focus is awarded to the category 'religion' as a crucial object of study, and an acknowledgement that "the distinction between religious and non-religious worldviews is not as clear-cut as we might have thought" (CoRE Commission on Religious Education, p. 32). The report heralds the emerging shift away from essentialised understanding of the six 'major world faiths' and promotes emphases underpinning the sociological study of religion; the varied and fluid nature of worldviews, the diversity in modes of practice and the importance of interactions within social, political and cultural contexts (CoRE Commission on Religious Education, pp. 36-37).

The findings presented here suggest that a turn towards the contemporary and the sociological is essential to the kind of knowledge and understanding that RE seeks to promote-whether viewed as preparing pupils as rational, autonomous subjects to make informed choices with regard to their own worldview, or as preparing pupils for interaction with diversity in society. Too reductionist an approach does pupils a disservice in either regard. The role and nature of religion and belief in society is complex and fluid-this article argues for a contemporaneous and sociological turn that helps pupils get to grips with that complexity. Such a turn is necessary in terms of the intrinsic value of understanding the world in which they live and in preparing young people for encounters with the religion and belief diversity of which they are part. This has begun to be recognised in emerging literature, for example on religious literacy of pupils (see Dinham and Shaw 2017) and in the proposed national plan for RE in England (CoRE), but has yet to be realised. This presents us with a pressing agenda for ongoing research and practice.

Funding: This work was supported by Culham St Gabriel's Educational Trust under Corporate Grant Number 113.

Acknowledgments: The research on which this paper is based was carried out by Martha Shaw and Professor Adam Dinham within the Faiths \& Civil Society Unit, Goldsmiths, University of London. 
Conflicts of Interest: The author declares no conflict of interest.

\section{References}

APPG (All Party Parliamentary Group on Religious Education). 2014. RE and Good Community Relations: Cohesive Schools-Cohesive Communities-Cohesive Society. London: UK Parliament.

Baker, Chris, Beth R. Crisp, and Adam Dinham, eds. 2018. Re-Imaging Religion and Belief. 21st Century Policy $\mathcal{E}$ Practice. Bristol: Policy Press.

Barnes, Phillip. 2006. The Misrepresentation of Religion in Modern British (Religious) Education. British Journal of Educational Studies 54: 396-412. [CrossRef]

Barnes, Phillip, ed. 2012. Debates in Religious Education. Abingdon-on-Thames: Routledge.

Barnes, Phillip. 2014. Education, Religion and Diversity, Developing a New Model of Religious Education. Abingdon-on-Thames: Routledge.

Bauman, Gerd. 1999. The Multicultural Riddle: Rethinking National, Ethnic and Religious Identities. London: Routledge.

Boyatsis, Richard E. 1998. Transforming Qualitative Information: Thematic Analysis and Code Development. London: Sage.

Catto, Rebecca, and Linda Woodhead, eds. 2012. Religion and Change in Modern Britain. Oxon: Routledge.

Chater, Markand, and Clive Erricker. 2013. Does Religious Education Have a Future? London: Routledge.

ComRes. 2018. Theos Religion and Violence Survey. Available online: http:/ /www.comresglobal.com/polls / theos-religion-and-violence-survey/ (accessed on 8 October 2018).

CoRE (Commission on Religious Education). 2018. Final Report. Religion and Worldviews: The Way Forward-A National Plan for RE. London: Religious Education Council of England \& Wales. Available online: https: / www.commissiononre.org.uk/final-report-religion-and-worldviews-the-way-forward-anational-plan-for-re/finalreportpic/ (accessed on 1 November 2018).

Council of Europe. 2008. Recommendation CM/Rec (2008)12 of the Committee of Ministers to Member States on the Dimension of Religious and Non-Religious Convictions within Intercultural Education. Strasburg: Council of Europe.

Davie, Grace. 1994. Religion in Britain Since 1945: Believing Without Belonging. Oxford: Blackwell.

Davie, Grace. 2015. Religion in Britain: A Persistent Paradox. Oxford: Wiley Blackwell.

Day, Abby. 2011. Believing in Belonging: Belief and Social Identity in the Modern World. Oxford: Oxford University Press.

Dinham, Adam, and Mathew Francis, eds. 2016. Religious Literacy in Policy and Practice. Bristol: Policy Press.

Dinham, Adam, and Martha Shaw. 2015. RE for Real: The Future of Teaching and Learning about Religion and Belief. Available online: https://www.gold.ac.uk/media/documents-by-section/departments/ research-centres-and-units/research-units / faiths-and-civil-society / REforREal-web-b.pdf. (accessed on 8 October 2018).

Dinham, Adam, and Martha Shaw. 2017. Religious Literacy through Religious Education: The Future of Teaching and Learning about Religion and Belief. Religions 8: 119. [CrossRef]

DSCF (Department for Children, Schools and Families). 2010. Religious Education in English Schools: Non-Statutory Guidance. London: Crown Copyright.

Fancourt, Nigel. 2015. Re-defining 'learning about religion' and 'learning from religion': A study of policy change. British Journal of Religious Education 37: 122-37. [CrossRef]

Foucault, Michel. 1988. Technologies of the Self. In Technologies of the Self: A Seminar with Michel Foucault. Edited by Luther H. Martin, Huck Gutman and Patrick H. Hutton. Amherst: The University of Massachusetts, pp. 16-49.

Grimmitt, Michael, ed. 2000. Pedagogies of Religious Education. Great Wakering: McCrimmon.

Hervieu-Léger, Danièle. 2000. Le Pèlerin et le Converti, La Religion en Mouvement. Revue Française de Sociologie 41: 395-98.

Jackson, Robert. 1997. Religious Education: An Interpretive Approach. London: Hodder Stoughton.

Jackson, Robert. 2004a. Rethinking Religious Education and Plurality-Issues in Diversity and Pedagogy. London: RoutledgeFalmer.

Jackson, Robert. 2004b. Editorial. British Journal of Religious Education 26: 219-21. 
Jackson, Robert. 2014. Signposts_Policy and Practice for Teaching about Religions and Non-Religious World Views in Intercultural Education. Strasbourg: Council of Europe.

Jackson, Robert. 2016. Inclusive Study of Religions and World Views in Schools: Signposts from the Council of Europe. Strasbourg: Council of Europe Publishing.

Jackson, Robert, Julia Ipgrave, Mary Hayward, Paul Hopkins, Nigel Fancourt, Mandy Robbins, Leslie Francis, and Ursula McKenna. 2010. Materials Used to Teach About World Religions in Schools in England. Research Report DCSF-RR197. Coventry: University of Warwick.

Lee, Lois. 2015. Recognizing the Non-Religious, Reimagining the Secular. Oxford: Oxford University Press. Available online: https://global.oup.com/academic/product/recognizing-the-non-religious-9780198736844?q= Recognizing\%20the\%20Non-religious:\%20Reimaging\%20the\%20Secular\&lang=en\&cc=gb\# (accessed on 8 October 2018).

Levitt, Peggy. 2006. God Needs No Passport: How Immigrants Are Changing American Religious Life. Harvard Divinity Bulletin 34: 45-57.

McCloud, Sean. 2017. Religions Are Belief Systems. In Stereotyping Religion-Critiquing Cliches. Edited by Brad Stoddard and Craig Martin. London: Bloomsbury.

Moulin, Daniel. 2011. Giving voice to 'the silent minority': The experience of religious pupils in secondary school religious education lessons. British Journal of Religious Education 33: 313-26. [CrossRef]

Moulin-Stozek, Daniel, and Bertram J. Schirr. 2017. Identification and Disidentification in Reported Schooling Experiences of Adolescent Muslims in England. Oxford Review of Education 43: 580-95. [CrossRef]

National Association of Teachers of Religious Education (NATRE). 2013. An Analysis of a Survey of Teachers on the Impact of the EBacc on Student Opportunity to Study GCSE RS—A Fifth Survey. July 2013 (v1.3). Available online: https://www.retoday.org.uk/media/display/NATRE_EBacc_Survey_2013_final.pdf (accessed on 1 November 2018).

Ofsted. 2010. Transforming Religious Education. London: Crown Copyright.

Ofsted. 2013. Religious Education: Realising the Potential. London: Crown Copyright.

Pasura, Dominic, and Marta Bivand Erdal. 2016. Migration, Transnationalism and Catholicism: Global Perspectives. London: Palgrave MacMillan.

REC (Religious Education Council of England and Wales). 2013. A Review of Religious Education in England. London: Religious Education Council of England and Wales. Available online: http:/ / religiouseducationcouncil.org. uk/educators/reports/a-review-of-religious-education-in-england (accessed on 1 November 2018).

Revell, Lynn. 2012. Islam and Education: The Manipulation and Misrepresentation of a Religion. Stoke-on-Trent: Trentham Books.

SCAA (School Curriculum and Assessment Authority). 1994a. Model Syllabuses for Religious Education: Model 1: Living Faiths Today. London: School Curriculum and Assessment Authority.

SCAA (School Curriculum and Assessment Authority). 1994b. Model Syllabuses for Religious Education: Model 2: Questions and Teaching. London: School Curriculum and Assessment Authority.

Sheedy, Matt. 2017. Religions are Intrinsically Violent. In Stereotyping Religion-Critiquing Cliches. Edited by Brad Stoddard and Craig Martin. London: Bloomsbury.

Stoddard, Brad, and Craig Martin. 2017. Stereotyping Religion-Critiquing Cliches. London: Bloomsbury.

Thobani, Shiraz. 2017. The Religious-Secular Interface and Representations of Islam in Phenomenological Religious Education. Oxford Review of Education 43: 612-25. [CrossRef]

Thompson, Matthew. 2010. Reflecting Honestly: Ideological Conflict, Religious Education and Community Cohesion. In Religious Education and Social and Community Cohesion: An Exploration of Challenges and Opportunities. Edited by Michael Grimmitt. Great Wakering: McCrimmon.

UK Parliament. 1988. Education Reform Act 1988. Section 9. Schedule 1. London: Her Majestey's Stationery Office. Available online: http://www.legislation.gov.uk/ukpga/1988/40/pdfs/ukpga_19880040_en.pdf (accessed on 8 October 2018).

UNESCO. 2006. UNESCO Guidelines on Intercultural Education. Paris: UNESCO.

Walsh, Robyn Faith. 2017. Religion is a Private Matter. In Stereotyping Religion-Critiquing Cliches. Edited by Brad Stoddard and Craig Martin. London: Bloomsbury.

Woodhead, Linda. 2012a. Plenary at New forms of Public Religion Conference. Cambridge: St John's College, University of Cambridge, September 7. 
Woodhead, Linda. 2012b. Religion in Britain Has Changed, Our Categories Haven't. Paper presented at Westminster Faith Debates, Whitehall, London, UK, May 2. Available online: http:/ / faithdebates.org.uk/ wp-content/uploads/2013/09/1335118113_Woodhead-FINAL-copy.pdf (accessed on 8 October 2018).

Woodhead, Linda. 2014. The "Fuzzy" Nones. Nonreligion and Secularity. Nonreligion \& Secularity Research Network, NSblog, March 7. Available online: http://blog.nsrn.net/tag/linda-woodhead (accessed on 8 October 2018).

Wright, Andrew. 1993. Religious Education in the Secondary School, Prospects for Religious Literacy. London: David Fulton.

Wright, Andrew. 2008. Contextual religious education and the actuality of religions. British Journal of Religious Education 30: 3-12. [CrossRef] 